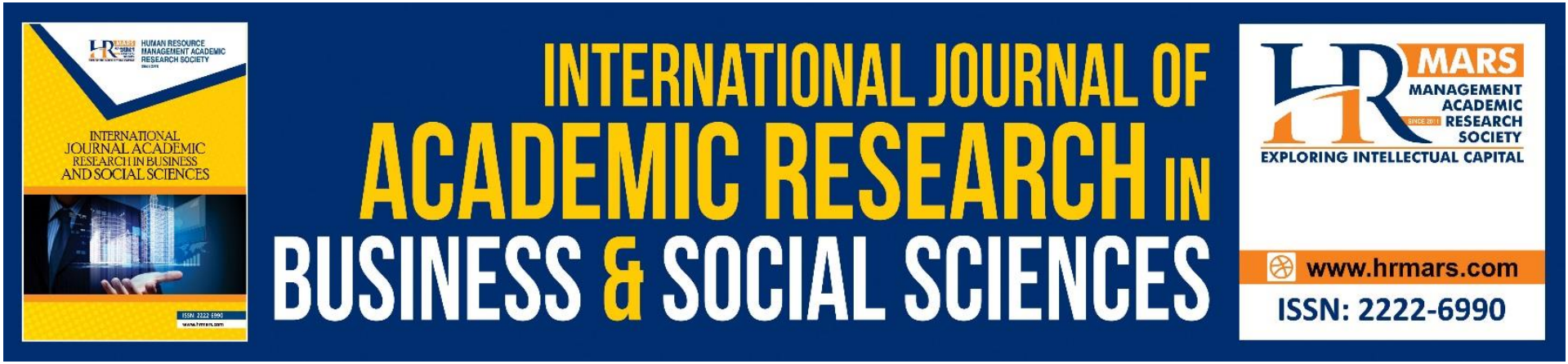

\title{
Defining The Future of Instruction in Hospitality Beyond Covid 19: A Hybrid Approach in Higher Education
}

Gerald Cloete, Simon Chiutsi, Joram Ndlovu and Sudesh Prabhakaran

To Link this Article: http://dx.doi.org/10.6007/IJARBSS/v12-i1/12050

DOI:10.6007/IJARBSS/v12-i1/12050

Received: 06 November 2021, Revised: 10 December 2021, Accepted: 27 December 2021

Published Online: 12 January 2022

In-Text Citation: (Cloete et al., 2022)

To Cite this Article: Cloete, G., Chiutsi, S., Ndlovu, J., \& Prabhakaran, S. (2022). Defining The Future of Instruction in Hospitality Beyond Covid 19: A Hybrid Approach in Higher Education. International Journal of Academic Research in Business and Social Sciences, 12(1), 306-318.

Copyright: @ 2022 The Author(s)

Published by Human Resource Management Academic Research Society (www.hrmars.com)

This article is published under the Creative Commons Attribution (CC BY 4.0) license. Anyone may reproduce, distribute, translate and create derivative works of this article (for both commercial and non0-commercial purposes), subject to full attribution to the original publication and authors. The full terms of this license may be seen at: http://creativecommons.org/licences/by/4.0/legalcode

Vol. 12, No. 1, 2022, Pg. $306-318$

Full Terms \& Conditions of access and use can be found at http://hrmars.com/index.php/pages/detail/publication-ethics 


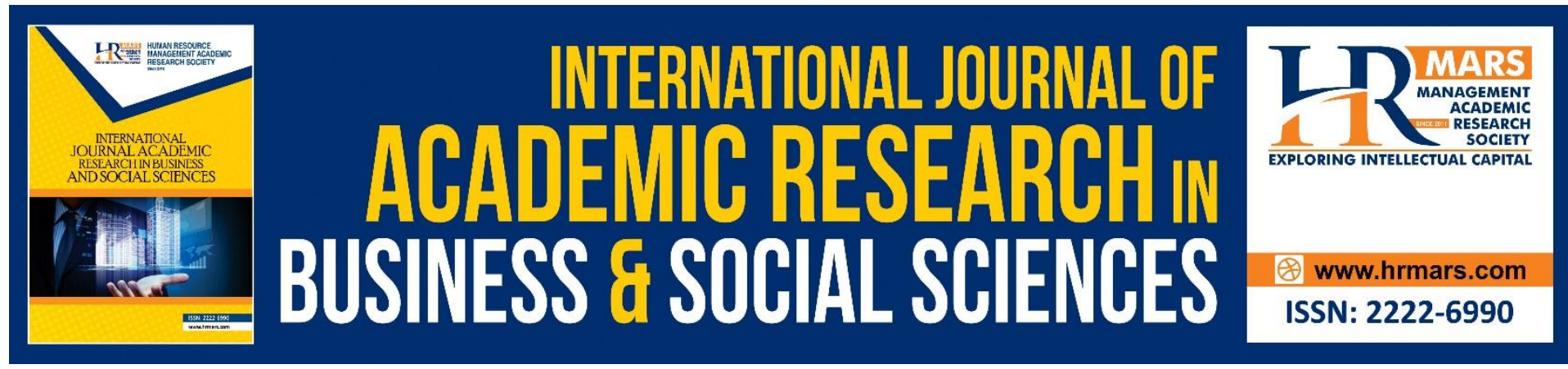

\title{
Defining The Future of Instruction in Hospitality Beyond Covid 19: A Hybrid Approach in Higher Education
}

\author{
Gerald Cloete ${ }^{1}$, Dr. Simon Chiutsi ${ }^{2}$, Dr. Joram Ndlovu ${ }^{3}$ and \\ Dr. Sudesh Prabhakaran ${ }^{4}$ \\ ${ }^{1,2}$ Lecturer, Namibia University of Science and Technology, ${ }^{3}$ Associate Professor, University \\ of Kwazulu Natal and ${ }^{4}$ Professor, Binary University of Management \& Entrepreneurship, \\ Malaysia
}

\begin{abstract}
Covid -19 has changed the normal way of teaching and learning in higher education. The traditional classroom teaching method are slowly becoming obsolete due to the introduction of non-pharmaceutical health protocols. Students are now forced to learn from home, face to face contact sessions has become a thing of the past and learning has changed dramatically. Homes have become new classrooms, online teaching has become the new norm and teaching in higher education has evolved tremendously. This paper seeks to examine appropriate approaches in teaching and learning in Higher Education Tertiary Institutions. A qualitative approach was used to collect data using a key informant technique. Interviews were conducted until a saturation level was reached, the data was then analyzed and categorized using themes. The results show that learning in Hospitality will take a hybrid approach in future, whereby online educational material will be combined with the traditional in classroom method to achieve acceptable education outcomes. Considering the nature of Hospitality Education, which is technical and vocational, which cannot be fully virtual nor fully digital, the teaching will require the physical presence of both lecturer and learner while providing the learner some control over time and space. The future of Hospitality education should have virtual elements of learning that are complimented with in-person lectures. The digital aspects of hybrid learning will allow for a unique acquisition of soft skills and the overall knowledge of business acumen. The in-person aspect will allow the imparting of vocational skills to ensure the learner acquire prerequisite practical skills and knowledge required in the Hospitality Industry. The paper concludes that Covid-19 has redefined teaching and learning in Hospitality Education and will continue into the future beyond Covid-19.
\end{abstract}

Keywords: Instruction, Hybrid Education, Hospitality, Covid- 19, Technical Skills.

\section{Introduction}

Covid -19 has changed the normal way of teaching and learning in higher education. The traditional classroom teaching method are slowly becoming obsolete due to the introduction of non-pharmaceutical health protocols. Students are now forced to learn from home, face to face contact sessions has become a thing of the past and learning has changed dramatically. 
Homes have become new classrooms, online teaching has become the new norm and teaching in higher education has evolved tremendously.

Zhao (2020) mentioned that the where of learning has been defined as a classroom in a school and learning is defined by what is happening in the classroom and or a special space at home. Schools went further and define where learning can and should happen. When schools were closed learning took place from home, learners took online courses, interacted with others online, did activities and assigned tasks online and thus learning can take place anywhere. Doucet (2021), argues that teaching and learning during the pandemic have been sidelined by a necessary shift to health, safety and wellbeing. The massive damages of Covid -19 may be incalculable, but in the spirit of rethinking it should not be about improving schooling, but should focus on the what, how, and where of learning (Zhao, 2021). He further mentions that all schools have globally been paused, some for a few weeks, some for much longer.

This paper seeks to examine appropriate approaches in teaching and learning in Higher Education Tertiary Institutions.

\section{Literature Review}

It is known that Covid -19 has ruined almost all segments of the global economic system (Hossain et al., 2020). Hospitality Tourism and Education was no exception at all. Mobilities were grounded due to stringent "new normal" policies that were put in place such as working from home, lockdowns, school closures, work integrated learning challenges, cancellation of events and public gatherings. Due to the interconnectedness of the Hospitality, Tourism, Service and Skills Training, there is a need to assess whether the responses of the Hospitality, Tourism and Culinary Art Lecturers, were effective in regulating, limiting, or terminating the spread of the virus and enhancing the Education sector. Doucet (2021), claim that educators will find recovery form the Covid 19 pandemic complex and prolonged. The recovery from Covid will require disparate cooperation from opposing parties. Therefore, putting lecturers on the frontline of connecting, learning, and leading to guide education systems through this period of rapid change and uncertainty.

Traditional mechanisms for holding schools accountable have also been paused, in Namibia government-operated accountability testing has also been removed this year with education entities such as International Board, the College Board, and the General Certificate of Secondary Education have suspended testing. Zhao is adamant that these pauses give governments and education leaders the very rare opportunity to rethink education, whether they want to resume accountability testing, given that students have been over-tested, and testing has itself become a pandemic in education (Emler, Zhao, Deng, Yin and Wang, 2020). In addition, what is of utmost importance is that the pauses provide schools a very rare and possible very short window of opportunity to recreate educational institutions.

It is further noticeable that the practice of applying the same content for all students has been challenged for a long time for two reasons as the same content does not meet the needs of all learners. Firstly, learners normally are allocated the same content based on their age, but age does not determine their abilities, as the content may be too hard for some and easier for others. Secondly not all learners need or are interested in the curriculum, as there is a strong interest in providing students the opportunities to pursue their own interest and need (Zhao, 2018a, 2018b). He further stresses the aspect of traditional teacher centered approach which has been challenged and criticized because of its lack of purpose. This approach request students to recite, repeat and remember meaningless knowledge, without any attempt to connect the knowledge to something in their lives and recommends the recent boom in 
Project Based Learning (PBL) and its various relatives which is a clear sign that the traditional methods of learning need to change (Zhao, 2020).

Zhao further states that it is important to remember that the changes to the what, how, and where of learning are necessary not because of Covid -19 but to create a whole new world, as we move towards the 4 th Industrial Revolutions in order to understand how our learners can learn better. He further argues that many schools in the world have already been thinking about innovative ways to deliver an education that is driven by students, that is more oriented towards purpose and meaning and is more global (Wehmeyer and Zhao 2020; Zhao, Emler, Snethen and Yin, 2019).

Covid -19 disrupted education and this aspect should inspire schools to think more about online education not as a lesser version of face-to-face education, but as a different way to organize education. In addition, inspire school leaders to reimagine education in terms of today's context and tomorrow's needs, thus from the perspectives of the children instead of the curriculum (Zhao, 2020).

One of the most appropriate methods of Instruction is Inquiry Based Instruction, which stresses the re- allocation of teaching schedules to boost the time allocated to teacher -led inquiry by up to 10 hours a week and encourages school systems to use teacher leadership to reinvent assessment with the aim of pivoting from current standardized testing to a more useful, improved -oriented accountability system (Doucet, 2021).

With the focus on leadership skills changes definitely have to be made in Hospitality facilitation and is been reiterated by the Report from Doucet (2021), which has an international focus and presents school systems and teachers with three waves of action. The now, The dance (Part past/ part Future) and the Transformation. The Now looks at teacher leadership, identifying ways they can share innovations with colleagues, parents, and policy leaders: how to address the social, emotional and academic needs of students as they return to school and the need for government to improve access to the technology students and their families require to participate fully with educators. The dance is a period in which educators can accelerate development of inquiry-driven learning teams and school systems can measure teacher leadership standards. Other aspects that also came strong forth was organizational skills, problem solving skills, safety training especially in Hospitality, food, and commitment of all those that are in Hospitality and Tourism.

Hard skills required in Hospitality to mention a few turns out to be coding ability, foreign Languages, computer skills, cooking skills, accounting skills and eventually communication skills. It is known that critical skills in relation to the pandemic relate to social distancing, health \& safety and infection control as well softer skills such as being aware of changing needs, actively looking for ways to help and managing uncertainty. This means that employees will need to receive training encompassing protection measures relating to the pandemic as well as enhanced customer service skills. Staff will also need to be enabled to take initiative and make decisions (Doucet, 2021; Al Qalhati et al., 2020).

It is a new world with new skills, and it needs professionals with new skills. Although the world will start to look more normal this year, the hospitality industry has changed as a result of the pandemic and will continue to be shaped by it in the immediate future. Sanitation and social distancing measures will continue to play a role in our lives throughout the year, as the virus is brought under control. Home delivery is going to continue to play a massive role in restaurant sales, with a number of the population now using a delivery application as compared to the period before the pandemic. The trend towards digital and contactless technologies has accelerated rapidly and the pandemic has driven changes in customer and 
staff behavior. Working from home is here to stay, with many companies adopting more flexible policies beyond quarantine. As a result, central business district (CBD) restaurants and bars have taken a downturn across the globe while suburban cafes are up in sales. Hospitality businesses that have struggled through the pandemic will be looking for fresh ideas and skilled new talent to guide them into recovery when the economy picks up again. The question that comes up is what skills will you need for a post-COVID-19 hospitality career? Hospitality will always require professionals who excel in skills that form the backbone of the industry such as customer service, culinary, food and beverage and management skills. It is known that during the last year, however, several skill sets have emerged as critical to businesses during the 2020 crisis. These skills are particularly in demand among professionals right now and will continue to be so, going into the future.

\section{Leadership}

"The days of a hotel manager in Namibia shut away in a back office are over. They will need to be multifaceted: even more present throughout the hotel, taking care of guests and staff, mobilising their teams, coaching, teaching, and leading by example."

\section{Soft skills}

Leadership is one of a whole spectrum of soft-skills that are going to continue to be in high demand in the post-corona hospitality industry. These include skills such as, critical thinking, innovation, creative problem solving, flexibility and adaptability, communication and emotional intelligence, self-awareness and self-management, negotiation, and relationship management

3. Social media, digital technologies and artificial intelligence (Al) range from contactless check-in systems to Al generated holiday packages, hospitality businesses have turned towards digital solutions during the pandemic and that trend is here to stay. Here are a few of the technologies we can expect to see continuing to play a role in the hospitality and tourism industry for the coming years: Food delivery applications doubled in usage during 2020, digital room keys and contactless check in systems in hotels, automated revenue management systems, touchless digital menus in restaurants, digital events and conferences are booming, big data and Al data analysis

\section{Sanitation and Housekeeping}

What are the Preferred approaches as the swing from classrooms to distance education has also exposed educators to the complexities of student's home lives, and the mental, emotional and physical strain facing school communities? The upshot is a renewed emphasis on meeting basic human needs before academic learning can be fully embraced. Thus," it is Maslow before Bloom" (Doucet, 2021).

Learners' experiences during the pandemic have reset their expectations for how teaching should be delivered. Academic Institutions plan to fully open campuses and resume classroom instruction this summer, but many students have said they want more choices for how classes are presented and delivered. This includes more online and hybrid learning options. A novel approach to hybrid teaching and learning described in a recent Echo360 webinar may give students the kind of flexibility they are looking for. Dr. John Drea, a professor of business at Illinois College described how he piloted a form of hybrid instruction called "The Choice Model." In his Harvard Business Publishing article, he shared the reasons why he developed 
and implemented the model, how his students reacted, and how he plans to integrate it into his course design in the future.

Arnove (2020), mentions that he would rather focus on what is learned and how it is learned. He guides that now is the perfect time to have students engage with a problem posing curriculum. Instructional content would involve students critically examining the issues that impinge on the personally, as well as on their families and communities. He further argues that recently a sociologist of education and university of Chicago professor Ewing, along with Chicago Teachers Union activist Jen Johnson, illustrated how students could compare incidents of the Corona Virus illnesses and deaths in their neighborhoods with those of other neighborhoods' with, for example a different socio-economic status (Ewing and Johnson, 2020). Along similar lines, while it is likely that most countries will blend online and in-person schooling for the foreseeable future, we can use online instruction to connect students within the across countries to learn about shared interest. These interests are likely to concern existential challenges to individual and familiar well-being like housing, food security, the quality of the water they drink, the air that they breathe and dramatic changes in the environment that threaten their communities (Arnove, 2020).

Arnove (2020), further reasons that such a curriculum would require a decisive move away from high stakes testing to more formative evaluations. They would involve, as is well -known, student portfolio's providing evidence of projects, encounters and various actions. Such actions may have beneficial outcomes, not only for the students themselves but also for those near and dear to them, reaching an expanding set of communities. He further argues that he advocated for education systems that have a necessary degree of autonomy, one opposing political indoctrination and a conveyor belt for prescribed, dehumanizing roles in inequitable, segmented and stratified economies. He was also an active critic of efforts to dismantle and privatize public education systems at their best, public school teach students to work with individuals from different backgrounds and learn a sense of social solidarity, not only with members of their own society but also with communities across the world. Besides teaching with analytical reasoning, high levels of literacy and numeracy, schools also can and should be teaching ethical commitments and enhancing aesthetic sensibilities, developing a commitment to social justice and a love of beauty. In addition, Arnove (2020), reckons that schools can teach respect for human differences and opposing points of view.

\section{Methodology}

The Research employs a qualitative approach, and ten (10) Hospitality, Tourism and Culinary Art Lecturers at the Hotel and Tourism School were approach for the semi structured interviews which was administered by the researcher himself and a $100 \%$ response rate was achieved. The researcher got ethical clearance in the form of a letter from our Associate Dean: Research and Innovation. Data was collected using a semi structured interview guide. A pilot study was conducted with $10 \%$ of the Lecturers at the Hotel and Tourism School. After the pilot study the interview guide was amended and utilized by the researcher to administer the personal interviews consisted of two parts; the first part identified, demographics such as age range, qualifications, area of specialization, and how long the person has been working / teaching in the Hospitality \& Tourism Industry / Institution and adhered to social distancing, wearing of a mask, sanitizing and related experiences. The second part referred to Teaching \& Learning, before, during and post Covid 19. Lecturers were interviewed until a saturation level was observed. A thematic analysis was used to evaluate the results. 


\section{Findings \& Discussions}

This section discusses the demographics of the lecturers (age range, qualifications, area of specialization and how long they have been working in the Hospitality \& Tourism Industry / teaching Profession. A $100 \%$ response rate was achieved, with thirty percent (30\%) of the respondents were males and seventy (70\%) percent were females, and thirty percent (30\% )in the age bracket of (31-40 Years), twenty percent (20\%) in the age range from (41-50 years) and twenty percent $(20 \%)$ in the age range from 61 and above and total years of experience in Hospitality and Tourism of Seventy five (75) Years all together. Twenty percent (20\%) were at a Bachelors level, twenty percent (20\%) were at a Honors level, Twenty percent (20\%) Masters level and ten percent (10\%) were at PHD level.

Twenty percent of the males were in the age range of (41-50 Years) and ten percent $(10 \%)$ in the age range of (51-60 years). Ten percent (10\%) of the males were on PHD level, ten percent on a Masters level and ten percent (10\%) on a Special Diploma level in Culinary Arts.

All lecturers had a Post Graduate Degree in Higher Education except for one lecturer that was still busy completing the last semester of the Post Graduate Certificate in Higher Education (PGCHE).

On the question what the most appropriate method of Instruction was during Covid -19, Sixty percent $(60 \%)$ of the respondents indicated that they focused on technology in the classroom whilst, fourty percent (40\%) said differentiation was the most preferred option for them. Arnove (2020), highlighted earlier in his career the importance of imagining community learning centers instead of classrooms and argued that there had been an absence of bold, innovative, and integrated approaches to the education challenges of the urban and rural poor in developing countries. The learning centers he proposed to UNICEF's assignment children would provide institutional context serving multiple needs in these populations with a range of programs and resources. In addition, he envisions these centers as meeting places where individuals of any age could go to take short courses, receive counselling, share interests, teach skills, receive health and nutritional care, and gain access to information on national, social services. He further recommended that the centers could utilize existing community facilities, houses of worship, recreational centers, health services, community action centers and of course existing schools (Arnove, 2020). The views on health and health care centers with nutritional care coincides with the views of Doucet.

Respondents were very excited about the question that focused on their preferred approach in facilitation and a $100 \%$ indication from respondents was in view of the blended (Online and Face to face) approach. This coincides with the views of (Doucet, 2021).

On the question what was your opinion about the future of Instruction beyond Covid -19 in Higher education eighty percent (80\%) indicated that a blended, hybrid approach would pave the way forward, whilst twenty percent $(20 \%)$ indicated electronic mediums which is of utmost importance in the 4 th Industrial Revolution. On the question how Covid will change teaching and learning in the future, Doucet is optimistic that such a momentous transformation can be achieved, but he is concerned that a desire to put the pandemic nightmare behind us as quickly as possible. Governments will cover the inequity it has exposed with policy band-aids that are cheap and easy to apply. The report encourages educators and governments to pause, reflect and invest in new education systems that addresses the root causes of inequality. He further stresses that discussions with stakeholders indicate a willingness to pursue measures that have the potential to close gaps. "One thing we do not highlight enough, is the importance of a good strong collaboration between unions 
and governments, when they work together, they can pivot more quickly and make things better for everyone "say Doucet.

With regards to higher education Arnove (2020), also addresses the issues related to disruptions in the international flow of students about the future beyond Covid-19. Many students have found themselves in dire situations where they are stranded at home without adequate resources or, with the eventual resumption of classes, without the means to return to their universities, while several major countries have depended on international students to finance their higher education systems and have done so in the most crass, instrumental terms. He further outlines that rarely have universities and colleges viewed international students as resources for reframing their curricula to include more global perspectives, neither have institutions, for the most part, adequately encouraged and supported the efforts of their faculty with international experience to incorporate new approaches to what and how they teach. As an alternative, internationalizing efforts have often been limited to pursuing new foreign markets, overseas campuses and partnerships with elite universities in geopolitically strategic countries. He eventually calls for higher education ethos that views internationalizing efforts as fundamental to a transformative, humanizing education (Arnove, 2020).

Smith (2020), argues with similar views from (Arnove, 2020) that it is quite possible that the business of higher education will be substantially altered by the social and economic effects of the Corona virus. As currently evidenced, the debate on both micro and macro levels continues about such matters as on campus student residency, modalities of instructional delivery and tuition rate increases or decreases. Smith (2020), posit three prominent themes to accent the post-covid-19 higher education administrative landscape, which are the possibilities of truth spinning, possible modality-based university, corporate partnerships and horizon thinking over bottom line preoccupations. Truth spinning is hybridizing the truth to gain favor, advantage or leverage over a person or group by purposefully deceiving them. To that end, truth spinning involves deception and unfortunately, truth spinning is becoming a common tactic publicly utilized by politicians especially in Namibia, corporate personalities, and the media. Moreover, higher education administration must make it clear that any attempts to defraud internal or external stakeholders of concise and accurate information regarding the organizational situation will not be tolerated. Smith (2020), further reiterate that if Post Covid -19 higher education institutions are to meet the challenges of reinventing campus operations dedicated to new learning platforms and respond to different and more competitive market environments, the foundation for responding must be complete trust generated by full disclosure to stakeholders. In sum higher education administration must present the factual trust to learners, parents, lecturers and support personnel via the exclusion of prohibition of administrative truth spinning (Smith, 2020).

Smith (2020) further mentions that as a result of the Covid -19 pandemic, nothing in higher Education has been made clearer than the prospects of increased online learning opportunities for students. He mentions that due to the largely immediate cessation of traditional campus-based, face to face learning situations, virtually all viable higher entities have either entered or increased activity in online domains. He further emphasizes that the application of increased levels of online programming is not suitable to all disciplines, especially in hospitality and a one size fits all mentality will prove to be ineffective. Smith (2020) insists and prompted by concerns that over both the spread of the virus and student welfare, most colleges and universities now include robust online learning components. Notwithstanding the laudable efforts of current higher education technology personnel to 
respond to this online learning crisis, Post Covid -19 requirements for online learning will far exceed current capacities and stresses that to be sure, the realities of a Covid -19 Higher Education business is technology, and lots of it. In addition, he mentions that advanced technological presentations for a very tech savvy client base will be warranted and not the status quo. Indeed, both the depth and span of online technology and learning must evolve if parents are to be convinced that tuition rates for online student instruction, which are generally lower than face to face models, should be commensurate with those that are campus based. Smith (2020), further argues that it is much more probable that modality of instruction will determine a sliding scale of tuition un-less new and improved higher education online learning techniques are introduced. Smith (2020), in agreement with Professor Scott Galloway's prediction that current higher education profits schemes, which unbeknownst to the public are astronomically high and very profitable and will reduce due to a Covid 19 consumer market that doesn't invest in the premise that present online learning and campus -based endeavors are similar in both cost and benefit. Smith (2020), concludes that rethinking the aspects of higher education, profitability and private technology partnerships to enhance the viability of a post Covid-19 educational marketplace seems attractive. The prevailing question is at what price? The question that remains is what might be sacrificed by higher education, as blended branding to include corporates with universities, fewer on campus students, reduced tuition and fees for students who pursue online degrees and the potential of private corporations having a permanent presence on campus could occur.

Well-known leadership experts John Maxwell often refers to the business concepts of the horizon and the bottom line and states that in a Covid -19 higher education environment, top administrative leaders need to refocus their thoughts from daily bottom line budgetary analyses and financial damage control scenarios to pursuing the institutional horizon where central leadership is more preoccupied with visioning, planning and goal-orientations dedicated to taking their organizations to where the future lies. Recovering from the pandemic now requires a shift to leading rather than managing and concentrating on moving higher education institutions to the horizon of productivity through conceptualizing an implementing new ideas related to the future of the academy under different circumstances (Smith, 2020).

The question that focused on the respondents' views on what their view was on the introduction of Non pharmaceutical Health Protocols especially in the classroom, were as follows:

"They are good and effective measures if it was handled correctly" another mention, it helps to lessen the spread of the of Covid-19. Though it cannot be sustained over long hours in class.

Another view was, quite safe, but not $100 \%$, however it assists in the elimination of the spread of the Covid -19 Virus.

Another view focused on the aspect of being "vital for the protection of both facilitator and the learners.

Other narratives were "Essential as it creates a safe environment for the lecturer and for the students enabling them to study at their maximum potential"... "Very Applicable,..."It's quite safe, even though it does not protect completely, ...but it reduces chances of contracting the Covid -19 Virus".

"Necessary ",...one mentioned,....." no idea"... whilst another mentioned that "she was not sure!" 
On the question to the respondents on what creative thinking techniques you apply in Hospitality, the majority, sixty percent $(60 \%)$ mentioned that they utilized gallery walk and mind mapping, whilst thirty percent $(30 \%)$ focused on story board, metaphoric and random words. In addition, ten percent of the respondents indicated that they include the following: mood boards, gallery walk, random words, storyboard, metaphorical thinking, and mind mapping.

Key elements in creative teaching also plays a vital role and the respondents revealed, that they mainly used roleplay, ninety percent $(90 \%)$, experimenting, ninety percent $(90 \%)$ and asking questions - seventy percent (70\%).

The respondents were asked what changes they introduced in their facilitation and their responses were as follows: Forty percent (40\%) mentioned that they included leadership changes in the classroom facilitation. Sixty percent $(60 \%)$ revealed that they made changes towards problem solving which is one of the major challenges especially in Hospitality with guests that complaints and challenges need to be sorted out. Addition changes that were introduced were fifty percent (50\%) and focused on commitment especially during the Covid -19 era. Faculty had to remain committed as it was extremely challenging to do things on your own. In some of the narratives of the lecturers it was evident that they also requested the students several times to be committed to make facilitation much easier not only for themselves but for the entire class group. One of the respondents, a lecturer in Culinary Arts revealed that she had to introduce once again Food Safety Training and Techniques during the Covid -19 pandemic just to ensure that no challenges were experiences with contracting the Virus.

The respondents were also requested to disclose what was the most important Hard skills required in Hospitality and the responses were as follows, communication skills was noted to be the majority with ninety percent $(90 \%)$ and was followed by computer skills that was sixty percent $(60 \%)$ which was then followed by cooking skills at twenty percent $(20 \%)$. Hard skills which also receive positivity as a requirement in Hospitality were staff Relations (10\%), adaptability (10\%) and finally accounting at ten percent (10\%) too.

The respondents had various positive answers towards the question that focused on how Covid will change the teaching and learning in the future and some of the narratives were as follows:

"...It will be done more and more on E-learning with less on face to face ...", ...another respondent "...revealed limited group teaching and more online instruction",... " Change it to online which will make it much more effective and efficient, as well as cost effective as it is so much cheaper"..." Covid has encourage learners to be independent and responsible for their own learning and allowed facilitators to be innovators in teaching and assessment".

An alternative respondent gladly responded,"... we might need to fully adopt online teaching in the future"...and "...E- Learning will remain key and Online resources more prevalent", ... better range of Teaching and learning tools".

One of the Respondents in Culinary Arts were adamant and mentioned "...Students will be willing to participate in online classes, take ownership of their learning, read more. It may be difficult to track struggling students...Wi-Fi is still a problem, so some students are not reaping the benefits of online learning, thus face to face material need to be combined " and "...Considering the nature of Hospitality Education, which is technical and vocational, which 
cannot be fully virtual nor fully digital, the teaching will require the physical presence of both teacher and learner while providing the learner some control over time and space".

A further respondent stated that "... many organizations are focusing on online and virtual meetings and learning...", ..." It will force us to use hybrid approaches to teaching and learning. These aspects were also several times brought forth by (Smith, 2020).

Indian Novelist and activist Arundhati Roy (2020) has described the current Covid -19 pandemic as a portal. He revealed that it is a pathway that leads to a reconfigured future, one that must be different from the world we previously knew. The pandemic's disproportionate, tragic consequences for health and livelihoods, for individuals and their communities, and even whole societies. This aspect of health and livelihoods coincides with the views of Doucet as well as Arnove (2020).

Hybrid learning was seen as quite positive and when the respondents were questioned on how do they think Hybrid learning will influence the future of teaching and Learning in Hospitality, some of them revealed the following:

"...Encourages lecturers to make the online class more interactive. Students will get acquainted with using computers not just for typing but learning as well".

"...It will become a permanent reality..."

"...It has already become the norm and will remain very important...".

"...It promotes active and deep learning as well as constructivism...".

"....It will open up and give both the facilitator and learner opportunities for different learning and teaching methods to suite the occasion and various needs...".

"...Institutions who adapt to hybrid learning will be the leaders in education and innovation...".

“...Hybrid learning will encourage teachers and lecturers to be more pro-active and to improve their skills in technology...".

"...More of the use of ICT in teaching and learning ...".

"...If used correctly and in the right way, it can actually make our teaching much more effective and a better student centred approach...".

Another respondent disclosed that "...Hybrid learning is towards one of the most significant benefits of technology which is digital learning. Also, a popular and contemporary trend in colleges and universities..."

Another pertinent question coming forth is how you think Hybrid learning will influence the future? The transformation suggests unifying the entire education system, from a pre-primary to higher education, with other community-based organizations to integrate physical and social-emotional health supports, after -school programs and workforce development training as a way to give educators the time to teach as well as lead. Government recognition of lecturer leadership through better compensation and workplace environments is seen as central to creating a coherent system of teaching, learning and caring. We cannot go back to an unsatisfactory status quo (Javed et al., 2020). As Covid -19's lessons compel us to imagine educations systems in which students of all ages can thrive (Arnove, 2020). In addition, traumatized students and their parents may have access to counselors and social workers focusing on inclusion (Ewing and Johnson, 2020).

\section{Conclusion}

The Covid -19 pandemic has made powerfully and painfully clear to us, that we are going thru a pathway to what we hope the readers of prospects will consider a once a lifetime 
opportunity, a chance to imagine more equitable societies and education systems and to the extent possible, take meaningful action to bring about that desired future. Arnove finally insists that it is an education that develops an emphatic capacity in individuals to view the world from the perspectives of people situated in radically different circumstances and involves the capacity to see differences then, to respect and to celebrate them. Such an education also enables all involves understanding their common humanity.

Covid -19 disrupted education and this aspect should inspire schools to think more about online education not as a lesser version of face-to-face education, but as a different way to organize education. In addition, inspire school leaders to reimagine education in terms of today's context and tomorrow's needs, thus from the perspectives of the children instead of the curriculum.

Learning in Hospitality will take a hybrid approach in future, whereby online educational material will be combined with the traditional in classroom method to achieve acceptable education outcomes. Considering the nature of Hospitality Education, which is technical and vocational, which cannot be fully virtual nor fully digital, the teaching will require the physical presence of both lecturer and learner while providing the learner some control over time and space. The future of Hospitality education should have virtual elements of learning that are complimented with in-person lectures. The digital aspects of hybrid learning will allow for a unique acquisition of soft skills and the overall knowledge of business acumen. The in-person aspect will allow the imparting of vocational skills to ensure the learner acquire prerequisite practical skills and knowledge required in the Hospitality Industry. The paper concludes that Covid-19 has redefined teaching and learning in Hospitality Education and will continue into the future beyond Covid-19.

\section{References}

Al Qalhati, N., Karim, A. M., Al Mughairi, B., Al Hilali, K., \& Hossain, M. I. (2020). Technology and HR Practices in Educational Sector in Sharqiya Governate of Oman. International Journal of Academic Research in Business and Social Sciences. 10(10), 435-443.

Arnove, R. F. (2020, June 02). Imagining what Education can be Post- Covid-19. Unesco IBE, p. 46. doi:10.1007/s11125-020-09474-1

Saza, C. E. N. (2019). Does size matter? Instructors' and Students' perceptions of students use technology in the classroom. (E. C. Scott, Ed.) Journal of Information Technology Education: Research, 18, p. 15. doi:10.28945/4411

Doucet, Armand. (2021). Teacher, Leadership in the aftermath of a pandemic: The Now, The Dance, The Transformation. New Brunswick, Canada.

Vincenti, G. W. T. (2020). Merging Sustainability and Technology in the Classroom: An Experience Report. In the 51 st ACM Technical Symposium on Computer Science Education . p. 15. doi:10.1145/3328778.3366899

Hossain, M. I., Polas , M. R. H., Rahman, M. M., Islam, T., \& Jamadar, Y. (2020). An Exploration of COVID-19 Pandemic and its Consequences on FMCG Industry in Bangladesh. Journal of Management Info, 7(3), 145-155. https://doi.org/10.31580/jmi.v7i3.1484

Javed, M., Hock, O. Y., \& Asif, M. K., Hossain, M. I. (2020). Assessing the Impact of Emotional Intelligence on Job Satisfaction among Private School Teachers of Hyderabad, India. International Journal of Psychosocial Rehabilitation. 24(4). 5035-5045

Mercer, N. S. H. (2019). Dialogue, thinking together and digital technology in the classroom; Some educational implications of a continuing line of inquiry. . Educational Journal of Education Reserach, p. 13. doi:10.1016/j.jjer.2017.08.007 
Kidson, P. K. L.-F. (2020). Co-designing Educational Policy: professional voice and policy making post-Covid. p. 10. Retrieved September 04, 2021

Singh, M. N. (2021). Inroad of Digital Technology in Education: Age of Digital Classroom. Higher education for the future.(8(1)20-30.2021), p. 11. doi:10.1177/2347631120980272

Smith, P. A. (2020). Lessons from Yalta:Considerations for post-Covid 19 Higher education. 5 Issue 1 (2020),(1(2020),pp.113-117), p. 5. Retrieved September 05, 2021

Zhao, Y. (2020). Covid -19 as a Catalyst for Educational Change. UNESCO IBE 2020, Prospects (2020)49:29-33, 5. Retrieved 9 28, 2021, from https://doi.org/10.1007/s11125-02009477-y 